\title{
AN ANALYSIS OF SAMA ORAL TRADITIONS ABOUT MONKEYS
}

\author{
Luke Schroeder \\ Graduate Institute of Applied Linguistics (Dallas International University), U.S.A \\ Kauman Sama Online \\ (luke-ruth@sinama.org) \\ DOI: https://doi.org/10.22452/brj.sp2019no1.7
}

\begin{abstract}
Monkeys are commonly found in the folklore of Filipinos and this is also true of the Sama. These stories under the surface give us insight into Sama self-perception as well as their perception of the more dominant groups around them. In this paper two Sama folktales are analyzed, i.e. "The Battle of the Monkeys and the Butterflies", and "The Battle of the Monkeys and the Sea Cucumbers". These stories give us an insight into how the Sama interact with neighbouring groups in Sulu. They also affirm, especially to children, character and cultural traits that the Sama perceive as morally upright. Through these stories the storyteller is expressing to his listeners that the Sama are industrious contributors to society and they are also brave and willing to stand up for themselves when necessary. Meanwhile other more dominant seeming groups are depicted as the monkey: brash, angry, and thieves. Also contained in these stories are lessons a child can learn about the environment and science that he needs to know for the context that he grows up in.
\end{abstract}

Keywords: folktales, indigenous literature, children's literature, animal tales, monkey stories

\section{Introduction}

"We bring blessing. All you [monkeys] do is steal."

This is the scolding that the butterflies have for the monkeys in the Sama traditional narrative, "The Battle of the Monkeys and the Butterflies". These two lines sum up the Sama projection of who they are in society and for their children, who they are to become. The characters that the Sama represent themselves with in their tales change from story to story, but the monkey is a recurring character and the lesson of his stories is: "Do not be the monkey." His character and the traits and persons that he represents are undesirable to the Sama.

In my study of Sama language and culture, I have elicited 5 stories that include monkeys: "The Child Who Becomes a Monkey", "The Competition of the Monkey with the Winds", "Grandfather Crocodile and Miss Monkey", "The Battle of the Monkeys and the Butterflies", and "The Battle of the Monkeys and the Sea 
Cucumbers". This analysis will examine these stories in light of the four functions of folklore: Amusement, cultural validation, education pertaining to knowledge of the world and also cultural knowledge and also the function of maintaining social control (Bascom, 1965). This analysis will pay special attention to the last two mentioned stories concerning monkey battles.

\section{Classification}

Sama monkey stories are fables, a common genre of oral traditions. Fables are a short story with animals as the main characters that teach a moral lesson (McKinney, 2000, p. 250). Each of the five stories fit into the animal tails classification of the AarnesThompson-Uther classification of folk tales, that is ATU 1-ATU 299 (Janssen, n.d.). "Grandfather Crocodile and Miss Monkey" seems to match-up quite nicely with ATU 58, "The Crocodile Carries the Jackal". "The Competition of the Monkey with the Winds" as well as "The Child Who Becomes a Monkey" most likely should be placed somewhere with the other wild animals found in ATU 79-ATU99. The stories of the "The Battle of the Monkeys and the Butterflies" and "The Battle of the Monkeys and the Sea Cucumbers" might also be appropriate with the other wild animals category except that it has certain similarities to ATU 103 category of war between wild animals and domestic animals. Sea cucumbers and butterflies don't match our idea of domestic animals, but these stories as we shall see certainly emphasize a superior character being exemplified by these creatures than that of the monkey.

It is important to examine how the Sama categorize these stories as well. In Sinama four of the five elicited monkey stories can be described as kissa or as kata-kata. The definition of these two forms can vary among the different Sama groups and communities. Generally, kissa can be glossed as 'a story'. Stories that are presumed to be make believe are called kata-kata, but kata-kata can also refer to a form of chanting about an epic story. My labeling of these stories as kata-kata subscribes to the former definition. This definition fits closest to the above etic category of fable. Some communities even consider it taboo to tell kata-kata during Ramadan since there is an element of untruth in the stories.

To call all the stories fables is not entirely accurate as fable is an etic category from a western vantage point which presumes fables to be false. A sub-genre or possibly similar genre of Sama literature to the kata-kata is that of usulan, traditional beliefs and stories. Several usulan cross over into what most researchers would categorize as fables. The stories tell of talking animals or children turning into animals. The term usulan however implies that the account is historical. Many of the usulan are traditional accounts of the origin of certain animals. The Child Who Becomes a Monkey fits into this category. I imagine in the modern world among the Sama there is some disagreement on whether the usulan are true stories, but I certainly have heard some Sama talk about incredulous stories that fit the category of usulan that they very much 
believed to be true. The moral lessons contained in these stories were therefore all the more powerful.

\section{The entertainment and educational value of Sama fables}

The fable genre is at a minimum dual purpose. They are meant to amuse which is one of the four functions of folklore (Bascom, 1965, p. 290) and is always present in fables. This function is primary. The audience is held captive by the performance and its entertainment value. However, simultaneously with the entertaining function of these fantastical tales is some form of education function. This education is from older generations passed on to the children.

The last two functions as defined by Bascom (1965, p. 292) are two forms of education. Many of the fables educate about the world the Sama live in or cultural knowledge, the third function of folklore. Also fables are especially known for providing moral or values education. This is included in the $4^{\text {th }}$ function of folklore, maintaining acceptable patterns of behavior (p. 294). They provide a social pressure for children or other listeners to conform in their society. According to McKinney (2000), "Oral traditions are multivocal; they can be used for entertainment and amusement, for transmitting culture, for justification of specific cultures ...for rationalization of beliefs and attitudes, for didactic purposes to teach values, morals, and acceptable behavior, for social pressure to sanction those who deviate from culturally acceptable behavior, for contest of wit, for explanations of cultural knowledge, for preservation of folk knowledge, and for protest of political inequality" (p. 262).

\section{Cultural and scientific education in Sama fables}

An example of an entertaining Sama fable with scientific knowledge is: "The Competition of the Flounder and the Pufferfish". This is a story of a hide and seek game among the fish where the pufferfish is able to win by intimidating his opponent into coming out of hiding. The process of entertaining the children with this funny story also allows them to hear stories of fish something that they are very familiar with culturally. The story points out where you would find fish hiding, and how they might be disguised as well as their unique characteristics. This is science and practical education.

In "The Competition of the Monkey with the Winds", we get to laugh as the monkey battles with unseen opponents. Eventually he will lose as he puts his hands up in surrender and falls to the ground. The falling monkey from the strongest wind is a mental image that entertains the audience, but at the same time children are being taught practical science that they need for their life. The maritime culture of the Sama requires that they know the characteristics of the winds. They will need it for sailing, for understanding fishing conditions, and also for protecting their homes and 
belongings. The story has the Sinama words for 4 types of winds and a description of how they blow. Being told this story helps them to learn of these winds while still young.

\section{Social control in Sama fables}

An example Sama fable that pairs an entertaining story with a moral lesson is the usulan of the little girl who doesn't listen to her parents but chooses to swim past dark. Her disobedience results in her turning into a mermaid and being separated from her parents forever. A Sama child who disobeys their parents about swimming alone in the dark could face the very real consequence of drowning. The usulan lightens the severity of the consequences. The child is still alive as a mermaid but loses her family. This warns children of the importance of obeying their parents.

The Sama monkey fables all combine this aspect of entertainment with an educational undertone. In the story o, "The Child Who Becomes a Monkey", children are presented with a familiar scenario, a child is throwing a fit at suppertime. This particular child's fit is because he didn't get enough food. His mother hits him on the elbow with a serving spoon. He starts to make the sounds and motions of a monkey and eventually becomes one. In the end he runs away from home not listening to his parent's calls for him to return. While it is entertaining to hear the storyteller make the "krut, krut" sounds of the monkey and see them gesture monkey movements, there is a lesson for both parents and children to take away. Children need to be content with the food they have. Parents shouldn't over discipline their child.

In the story of "Grandfather Crocodile and Miss Monkey", a crocodile asks for an undesirable payment for Miss Monkey in order to cross the channel. She agrees to the payment but tricks the crocodile and gets off on the other side of the channel without paying him. The monkey's deceit will not go unpunished. Sometime later she is gathering shellfish at low tide and comes across what she perceives as the corpse of Grandfather Crocodile. When she is alone and helpless, he attacks her exacting his revenge on her.

In this story a powerful lesson is taught about revenge as well as deceit. Revenge is a powerful force in Sulu. The Tausug people are especially renowned for how they take revenge (Hunt, 1920, p. 36). This story teaches the lesson to either deal with the Tausug honestly or not at all since you will most likely experience their revenge at a time where you were not expecting it. I wish to take extra care to note that this story is talking about values of revenge and justice that in the current cultural context of Sulu fit into the Sama perspective of the Tausug people. This is a generalization made by Sama in their communities who have firsthand and secondhand accounts of grievances that they or relatives have experienced with the Tausug. It is possible that this story in its original form did not intend to single out the Tausug in associating them with violent revenge. 
My experience is that this combination of entertainment and education in Sama traditional stories is prevalent in virtually all the stories I have elicited. It is certainly present in the stories, "The Battle of the Monkeys and the Butterflies", and "The Battle of the Monkeys and the Sea Cucumbers". These two stories specifically speak clearly into the Sama projection of themselves to their children and how they interact with society as a whole.

\section{Analysis of two Sama fables}

\section{Two Stories of Battles with the Monkeys}

On September 18, 2013 I was told two stories by an old partially deaf Sama fisherman, Bapa' Kinista. The stories were told right after I had met at Bapa' Kinista's home with several of the community's elders. At one point in the meeting I shared with the men four children's books that we had made and published in Sinama. Two of the stories were crafted stories of Sama men and their experiences fishing. Two were oral traditions from other cultural contexts different than that of the Sama. In the past I had asked this man in one on one personal interaction if he could share with me some of the oral traditions of his people. However, I had never been able to elicit any from him. He would only laugh and let me know that he recognized the few stories I had collected from other members of the community.

When the others had left, this approximately 90-year-old man confided that he had a story I should know. His wife and middle-age son agreed. With his wife, son, and granddaughter present, he told me a story about monkeys and their battle with the sea cucumbers. Then very naturally he transitioned into a second story: that of of the monkeys and their battle with the butterflies. I was given verbal consent to record the stories and to eventually publish them on my Sama cultural website. The two stories are related and therefore have similar theme, genre, characters, and moral lesson.

\section{"The Monkeys and the Sea Cucumbers" (synopsis)}

The development of the first story is rather abrupt. The first sentence simply states that there is a scheme being made. The second sentence tells us that those scheming are the monkeys and the sea cucumbers. Abruptly by the third sentence the sea cucumbers have come outright and tell the monkeys, "No matter how many of you attack us, we will fight you." The monkeys gather their forces. The meeting time is at the full moon. This is the highest and lowest time in the month of the tide. Both a multitude of sea cucumbers and of monkeys express that they are eager for low tide.

When low tide comes, the monkeys run out to the sea cucumbers and start stomping on them. All sorts of sea cucumbers were there. The monkeys were destroying the sea cucumbers. When they brought a report to their leader, he asked if they had finished them all off. The answer was not yet, because the leader of the sea 
cucumbers, the bāt tagokan (specific sea cucumber species) was still out there. They had stomped on this kind of sea cucumber, but they could not get its innards off of their feet. Instead the monkey was stuck (this is what this particular sea cucumber is known for, being very sticky). Unable to leave his position on the edge of the ocean and with high tide coming in, the stuck monkey very seriously tells the sea cucumber to stop it. The sea cucumber refuses. This was what the monkeys and sea cucumbers had agreed upon. As the tide comes in, the monkey cannot escape. He ends up dying, demonstrating the sea cucumbers' victory over the monkeys.

\section{"The Monkeys and the Butterflies" (synopsis)}

The second story is about a fight between the butterflies and the monkeys. This time it is clear that the monkeys pick the fight. They belittle the butterflies, telling them they are good for nothing - they are mere worms, caterpillars.

The butterflies respond that they are useful and that the monkeys could not eat without them, for they are the ones that pollinate plants. The monkeys do not believe them. They ask for a fight. The butterflies say that's what they are here for.

Again, a multitude of monkeys and of butterflies arrive. The monkey leader orders that the butterflies go first. A butterfly advances and lands on a monkey's forehead. The monkeys have clubs. A monkey is ordered to club the butterfly. He misses as the butterfly takes off again and the monkey nails his comrade on the forehead who is knocked off his feet. The injured monkey wonders why his comrade clubbed him (not realizing that a butterfly had been on his forehead).

The next time a butterfly is ordered to land on the monkey's knee. The result is the butterfly escaping and the monkey's knee being injured. The monkey leader says that if this happens again, they will have to surrender out of fear that they will be destroyed.

Sure enough, another butterfly, a large one, lands on the monkey's other knee. For a third time, the butterfly is able to fly away, as the monkey's other knee gets clubbed. The monkey writhes in pain. He is now crippled. The monkeys surrender and the butterflies lecture them, "We [butterflies] bring blessings. All you [monkeys] do is steal." The storyteller then asserts, this is true. Monkeys are troublemakers or rascals.

\section{The entertainment function of the two stories}

Before analyzing the content of the stories, there are some notable things about the form that should be mentioned. The storyteller told these stories in an animated fashion. He would make motions that helped you interpret the story. When the monkey was stepping on the sticky sea cucumber he would point to the bottom of his foot. When a monkey was getting ready to club a butterfly, he would pretend as if he had a club. When a monkey got hit on the head, he would hold his head and when they got hit on the knee, he would hold his knee. The continual laughing of his wife 
and sometimes his granddaughter encouraged him to be all the more animated in his actions.

His voice was also animated. Because of this, he did little to introduce who was talking in the stories. You had to determine who the speaker was by both the context and by the variety of voices he was mimicking. This quick back and forth dialogue made it possible to imagine real conversations going on between these animals. Also he used sound effects for the monkeys upon their arrival "ho ho ho ho" and would mimic monkey gestures with his arms.

\section{Storytelling as an entertainment is decreasing among the Sama}

In 1946 Stith Thompson wrote, "For a large proportion of the world's inhabitants the traditional tale is even today one of the principal forms of entertainment. Books, the cinema, and the radio have not yet changed age-old habits among people essentially out of the reach of these modernizing agencies (Thompson, 1946, p. 449). Now we live in a world where these agents of change are becoming all the more prevalent along with new inventions like the internet and cellphone. We can expect that indigenous literature dating back for centuries from oral societies is threatened in most all places in the world.

Unfortunately, Bapa' Kinista's skillful performance of these two stories, as evidenced by the entertaining aspects that he wove into his stories, is an art form that is now decreasing in Sama communities. As a 90-year-old, most of Bapa' Kinista's peers have passed on ahead of him and he too has now gone on ahead to his final home. He came from a generation that did not yet have access to internet or television. Even radios were most likely less common among the Sama and certainly not something you could take out with you fishing.

Storytelling was a more prevalent form of entertainment in Bapa' Kinista's generation. It is my experience when searching for entertaining Sama stories, those I ask often regret that a certain storyteller that they were an audience for from a previous generation no longer lives. Whoever that person may have been, whether a grandfather or an uncle or their father, according to my conversant, that storyteller could have provided me with a wealth of wonderful oral literature of the Sama people. However, the person telling me this felt that they personally had forgotten the stories or cannot tell them in a way that does the story justice. Due to the increase of other forms of entertainment and the decrease in indigenous story telling these two stories along with other stories that we can gather from Bapa' Kinista's generation and the one that followed are cultural treasures.

\section{The scientific education function of the two stories}

These stories about monkeys teach Sama children basic lessons about their environment. In the story of the monkeys and the sea cucumbers, the Sama teach their 
children the variety of sea cucumbers by including them in the story. Sea cucumbers have in the past been one of the more lucrative fishing enterprises of the Sama. Certain sea cucumbers have really sticky innards. The story defines these for the children: Gamat, sandulay, and tagokan, with tagokan being the stickiest.

The setting of the battle of the sea cucumbers with the monkeys is also a science that the Sama depend on. The best time for a land creature to fight an ocean creature is at the full moon at a time where the tide recedes the farthest exposing the habitats of many sea creatures including the sea cucumbers. If a monkey were to find himself stuck on a sea cucumber and the tide were to come in as specified in the story, indeed the tide would be at its highest point in the month thus allowing for death of the monkey by drowning.

Basic science is also included in the story of the monkeys and the butterflies. The children learn that butterflies pollinate the trees, providing food for many creatures. This is a basic observation about how the natural world works that the Sama has observed and made use of in his stories. He thus passes that knowledge on to his children.

\section{The conflict motif in the monkey battle stories}

The theme for both battle stories jumps out as being the same, hence their being told together, one after the other. They are stories based on violent conflict between rival groups. Yet interestingly enough Sama as a whole define themselves as a peace-loving group. The storyteller himself has attested to this, this is often a claim that Sama community elders will assert, and as is my experience also, this is one of the very first attributes that Sama will tell you about their people when interviewed in their communities throughout the Philippines. This characteristic is also frequently mentioned in ethnography about the Sama. Richard Stone (1974) mentions it in his article: "With pride and some defensiveness, [the Sama] see themselves as a very peaceful group" (p. 156).

So how can it be that a peace-loving people have developed fables of violence and battle? In some cultures, these stories would be deemed too violent for children. As this fable was being adapted for a children's book version of "The Monkeys and the Butterflies", the Bisayan literacy consultant asked if the story might be too violent to be useful. I consulted the storyteller as well as another Sama informant. Both felt the story appropriate for children.

This story seems harmless enough for an audience of children, but there are other Sama stories that were presumably for children that my cultural sensitivities deem inappropriate for children. A Sama man told me the story of "Grandfather Crocodile and Miss Monkey", a story having several sexual aspects, concluding with the crocodile raping and murdering the monkey. I published the story with several details changed. A Sama reader recognized that I had changed the story and asked 
about the true account. Her understanding as an insider is that Sama culture is more open in areas of violence and sexuality. There is most likely a need for more openness in the area of violence, because Sama children who grow up in Sulu are more likely to be exposed to more actual violence than other Filipino and Malaysian people groups.

These two stories were told in Davao where the Sama enjoy a state of relative peace. Escaping war and violence in their homeland is among the top reasons why most of the Sama communities on the coastlines of Mindanao have left Sulu. This is true for the Sama communities in Davao who migrated over half a century ago. Sulu on the other hand to this day remains a place where violence is common. In the Davao community news would arrive of war in their homelands. Not political war, but feuds between families. One such news being that the Sama of Silompak and Kūd-Kūd, relatives of those in Davao, were at war with Tausug bandits from the mainland.

The storyteller came from Siasi, Sulu. He had intermarried with the Sama from the fishing village of Silompak, also considered Siasi. His place of origin is Kūd-Kūd, a village built over the tidal flats fronting Manubal village on Lapak island. Those in Kūd-Kūd transferred there from Musu' a village built over the water, fronting Siasi island. All four places are Sama communities. Before when living in Musu', they had befriended Tausug from the inland of the island and shown them hospitality. At some point the Tausug betrayed them and violently stole their valuables (gold being an important treasure to the Sama). This relationship between Sama and Tausug will be discussed later in this analysis.

It is said by those in Davao that the Sama of Kùd-Kūd are fighters at least in comparison to the other Sama villages in their area. These battle stories could possible originate from these Sama of Siasi and be a reflection of some of the violent conflict they have experienced over the years or it might have been passed on to them by other sources. For instance, the story of the butterflies and the monkeys can be found transcribed in Yakan in a more complete form from as far back as 1973 (Behrens \& Pack, 1973). Whether the story originates from the Sama themselves in Siasi or not, it is apparent that the theme of this story certainly resonates with the Sama of Siasi since it was retold 40 years after it was transcribed in the Yakan language.

\section{The monkey character as metaphor and the social control function}

A common feature of animal tales is that the animals are designed to show the cleverness of one animal and the stupidness of another (Thompson, 1946, p. 9). This is blatantly apparent in the monkey battle tales. The storyteller introduces the characters early on in the stories. Monkeys are the antagonist in both stories. Monkeys are a common character in Filipino stories. "The Monkey and the Tortoise" is a very famous Filipino traditional narrative. It was made popular in the English language by Philippine national hero José Rizal in 1889 (Rizal, 1889). Out of the five Sama fables mentioned in this paper, four of them have the monkey losing in the end. In the 
remaining story, the story where the boy becomes a monkey, becoming a monkey is an undesirable outcome for a child. In the Filipino story, the monkey also is portrayed as stupid and a loser. He loses in that he picks the wrong half of a banana tree to try and replant in the ground. He also loses in that he fails to kill the turtle. In three of the Sama stories the monkey is tricked. In the Filipino story his plan to kill the Turtle by drowning, something the turtle says he is afraid of, backfires on him. The turtle is a natural swimmer and escapes easily.

We see here that the monkey is most often depicted by Filipinos and especially the Sama as a trickster, a stupid, rash, overly angry animal, who is quick to resort to violence. Rizal's (1889) description of him is this: "...the monkey plays the same part, greedy, malicious, wicked, and revengeful." If the monkey symbolizes a person or group, it is than undesirable to be this character since the monkey is the one being laughed at in the stories.

Here we have the function of social control. The Sama do not want to take on the character traits of the monkey who is made out to be foolish in both of these stories. He is therefore passing on admonitions in these stories to not be rash, overly angry, quick to resort to violence. Do not be the monkey.

\section{The monkey character and Sama commentary on political inequality}

It stands out that in these two stories the monkeys could represent the relationship the Sama have with the Tausug. The Tausug are the monkeys and the Sama are the protagonists in both stories, the sea cucumbers and the butterflies. The setting of the sea cucumber story helps give a basis for deducting that the monkeys represent the Tausug and the Sama are represented by the sea cucumbers. Tausug make their living off of agriculture while Sama make their living off of the ocean. The Sama villages in Siasi are mainly over the water, while the Tausug villages are sometimes on the shore, but often inland. The Sama in Davao would often insist that the Tausug don't know much about boats or fishing. This has always made me wonder since it seems there are quite a few Tausug who are also fishermen. However, the Sama stereotype the Tausug as land people.

In the story, the two groups, monkeys and sea cucumbers, can only interact with each other at the time of the month when the tide rises and falls most drastically. The Sama like the sea cucumber, belong in the sea. The Tausug like the monkey belong on the land. Cultural differences for the most part keep Sama and Tausug interaction separate. They have their own villages. When the populations mix, conflict tends to arise.

In the second story, the Sama are depicting themselves as the butterfly. There is a possible metaphor in the story of the butterfly for the Sama defense mechanism. Sama tend to handle conflict by leaving. Originally the Sama were nomadic boat dwellers. If a problem arose, avoiding the problem was just as simple as taking your 
boats elsewhere. For the land based Sama, like the Sama of Silompak and Kūd-Kūd, there is no cultural memory of living on boats, but the principle remains the same. When conflict or trouble arrives, Sama leave. The interesting thing in the butterfly story is that the butterfly is protecting itself by quickly leaving from his landing spot on the monkey. The end result is that the monkey ends up beating up his fellow monkey.

I have heard Tausug call Sama cowards and fearful. The concept of leaving in order to avoid conflict is a stark contrast to an idea that exists in many Tausug that it is better to die than to be dishonored. Though the Tausug looks at the defense mechanism of the Sama as cowardly, the Sama's viewpoint is that it makes sense and in the end the Tausug looks like the fool.

This conclusion that the Sama are symbolizing the Tausug with the monkey in these two stories is limited only to these two stories and may only exist in this storyteller's rendition of the stories. For instance, I am not familiar with how the Yakan interact with each other or neighbouring groups in Basilan and Zamboanga. Their version of the story differs from this one and may have less meaning associated with it or refer to different conflict related problems that the Yakan observe in their communities. The other three Sama monkey stories mentioned in this paper do not allude to the Tausug tribe as the monkey in the stories. The monkey is used in the three other stories to discourage foolish or disobedient behavior.

Also, I have generalized the viewpoints and cultural traits of both groups. An individual Sama or Tausug may differ from the others in his community and one community of each group may be different than the next. After interactions with multiple Sama communities and dialect sub-groups, I can attest that there is enough distrust of Sama towards Tausugs in their communities that concluding that the Sama would critique the Tausug in their fables is not a stretch by any means.

\section{Moral lessons}

In Sulu, the Tausug are considered dominant. The Sama are considered inferior. The Tausug tend to think of the Sama as cowards and below them. The Sama tend to work under the Tausug. Though the Tausug might express his dislike for a Sama or his low view of the Sama in the presence of the Sama, the Sama would be less likely to speak lowly of the Tausug in his presence. Yet they do all the time when it is just Sama around. Many times I was told, "Don't trust Tausug. They are traitors." "Don't assume that a Tausug is your friend. He will betray you. It is what happened to us in KūdKūd." The bandits of Sulu, at least from the Sama cultural narrative, are not Sama, but Tausug.

Through these fables, the Sama can express his dislike for the Tausug and to warn his children about them. The monkey is depicted as being brash and always wanting to fight. The Sama do not depict themselves in the story as cowardly, but 
instead ready for the fight. The stories in themselves give the Sama the chance to call the Tausug foolish by comparing him with a monkey, without having to admit that these monkeys are indeed referring to the Tausug. This fits well with what Arensen says of folktales, "One great benefit of analyzing tales is that since they are told about non-real characters in a remote time, the storyteller can deal with sensitive issues" (1991, p. 200). Here the Sama get to address a political injustice they are keenly aware of without outright offending their neighbours the Tausug in Sulu.

It is worth mentioning that though I believe that this telling of the story of the monkeys and the butterflies fully intends to make a comparison between Sama and Tausug groups, it can also be extended beyond this. A Facebook post of an acquaintance of mine quoted the banter of the butterflies towards the monkeys when referring to the Zamboanga Siege in 2013 that was a conflict between the MNLF and the Government of the Philippines: "All you do is steal. Rascals." If my understanding of the context is correct it was an accusation against the Philippine government for driving the residents of Rio Hondo from their land, though it could have possibly been in reference to either group.

The monkey in the story belittles the butterflies. He says they are useless. Many Tausug may realize the value of the Sama, but they certainly don't value them like they do their fellow Tausug. Yet some would argue that it is the Sama that built the wealth of the Tausug sultanate. J. Hunt says this in his 1837 work entitled "Some Particulars Relating to Sulo, in the Archipelago Felicia": "The most industrious and useful race of men about Sulo and the circumadjacent islands, are the Badjows or orang laut; to these men Sulo is principally indebted for her submarine wealth" (Hunt, 1920, p. 72). Badjows here may refer to a subgroup of the Sama, the Sama Dilaut or it may refer to the group as a whole, since there is much confusion on the names for Sama in the region.

Therefore, the story of the monkeys and the butterflies affirms in the Sama child that he is not worthless. Without the butterflies the monkeys would have nothing to eat. The Sama see their providing fish, pearls, and other sea treasures as a productive contribution to society. Without the Sama it is asserted that the Tausug would not have these things. Also expressed is the Sama abhorrence for easy money through pirating, of which the Sama are often the victim. It is interesting that the second story is very explicit in stating its moral: "You are nothing but thieves" and "We butterflies help people." This is also to instill self-esteem in the child. The Sama are hard workers. They too provide Sulu markets with their fish. Stealing in the story is shamed. Shame is a much more powerful force in Sama culture than in western. Children are taught to help and be productive. They must not make their living off of stealing.

The story of the monkeys and the sea cucumbers affirms in the child that he is not defenseless. In many ways a sea cucumber looks completely defenseless against the monkey and indeed, many of the sea cucumbers do get destroyed in the story. In the end, however, it is the sea cucumbers who get the last laugh, because the monkeys 
were completely not expecting the sea cucumbers ability to get them stuck until the coming of high tide.

The Sama see themselves as particularly adept in their environment, the ocean. This is expressed through a conversation I had with an in-law. He surprised me, by calling Tausug cowards. This is not a normal thing for anyone to say, probably throughout the entire Philippines. I asked him why. He said that Tausug won't attack you to your face and they won't pick a fair fight. They will attack you when you don't expect it and they will gang up on you. He said, "Challenge a Tausug to a fight out on the ocean, one on one, and he will never accept it. He's a coward." It is interesting that the fight of the monkeys and the sea cucumbers happens on the ocean.

This perspective where a Sama is confident in their ability to defend themselves on their own terms was reaffirmed by a conversation I had with an elderly Sama lady in a Sama fishing village in Maasim, Sarangani Province. I had asked the woman if it is true that the Tausug that interacted with the Sama in past generations were more honorable than the Tausug they interact with today. She said that things became different as guns became more available in Sulu. In the past the Tausug acted more honorably towards the Sama because they were afraid to fight the Sama since swords and other blades would be at a disadvantage against spears, clubs, and spearguns. The guns had come with the wars of the 70s and onward and now the Sama are accustomed to being bullied and pushed around by Tausug where disputes with them could often prove fatal. It is worth noting that even now, the Sama who have remained in the Siasi area arm themselves as well. They used to go out with only their spearguns, but now must and do carry real guns in order to ensure their livelihood.

\section{Implications of the Sama projection of himself}

In these stories the Sama by identifying with the protagonists have demonstrated that they are proud of who they are and recognize the value that they have as people in society. The stories also serve to counteract an image projected on the Sama by the Tausug people. Sama are not cowards and are ready to stand up for themselves. These stories thus pass on this positive self-image to the younger generation who are the audience of the storytellers.

This oral tradition analysis reiterates the findings that Richard Stone had in his 1974 article about the relations between the Tausug, Sama, and Badjaw. In 1974 Stone noted this of the Sama, "The Samal may be relatively secure in their group image and consider themselves a 'better group' of people for a variety of reasons" (Stone, 1974, p. 92). Some of these variety of reasons are found in our story. The Sama are not thieves. The Sama work hard for a living and they provide food, not just for themselves but for society as a whole. The Sama way of dealing with conflict is less likely to be violent, but rather avoidance. A Sama however when pressured is also brave. 
In the same article Stone quoted another interview of a Tausug in Jolo concerning the Sama, "Without the [Sama] there would be no market place. The [Sama] are the fishermen of Sulu. Tausug are not good fisherman and it is necessary for the [Sama] to supply the market place with fish if the people are to live normally here" (Stone, 1974, p. 82). This quote is proof that both the Sama and the Tausug can see this role that the Sama play in society.

\section{Implications of the Sama projection of the Tausug as the monkeys}

When following these stories to the logical conclusion that these particular Sama are commenting on how they view the Tausug, immediately the thought comes to mind of how offensive this must be to the Tausug. Is it an injustice to describe the Tausug tribe as traitors, stupid, rash, overly angry and quick to violence? First off it is important to hold on to the fact that these are stereotypes and generalizations. They do not hold true for all. What this analysis does bring to light is that racial or more accurately tribal relations among the Sama and Tausug haven't improved over the years. Many of my correspondence with Sama in community from 2010 to the present have produced the same data that Richard Stone's findings from 1974 showed. That was almost two generations ago.

All the more this shows that the stories that we tell our children will impact their reality. The Tausug have suffered many historical grievances. Their response has been one of courage and that of a warrior. They comprised the ruling class of the Sulu Sultanate and they fought off Spanish, American, Japanese and Filipino soldiers in their territories. The Tausug child therefore hears stories of prior glory. He hears that he is the nobility and also hears that he is better than others around him. He also hears that he has been wronged and hears how his ancestors were never afraid of a fight. This character that he develops will impact his view of how he treats the other groups of people around him. There are positive things that a Tausug child can learn from this narrative, but there are pitfalls as well. Effectively by comparing the Tausug to a monkey, the Sama storyteller is discouraging his children from falling into these pitfalls. This is even more important when you consider that many of Sama heritage are adopting the identity of Tausug, having more pride to be known as a Tausug than known by the cultural heritage of their ancestors.

\section{Dangers of embracing a pitiful projection of one's self-image}

I am most attracted to these two stories about monkeys because of how positive of a self-image the Sama project upon themselves in the stories. I think it encourages Sama children to try harder. This positive self-image as expressed in the story can help Sama children at times when they may face derision from others. If a Sama is called a coward, it is helpful for him to know that he is not one. It also puts the thought into a Sama child's head that he is not defenseless 
In contrast, I have a growing concern for what a culture of begging has done among the Sama Dilaut, the subgroup of the Sama known in the Philippines as the Badjao and what impact this could have on the Sama as a whole. The Sama Dilaut in mainland Mindanao and throughout major cities of the Philippines have become known for their street begging. For the art of begging the children, women, and men who engage in that activity must project themselves as pitiful for greater financial benefit.

The plight of the Sama Dilaut is real. Their homelands were and are ravaged by war. In urban contexts it is becoming less and less possible for them to apply themselves to the fishing industries that traditionally they were able to sustain their families and communities with. Education has not been geared towards their needs and they have not in most cases succeeded in the educational institutions of the Philippines. Everyday a Sama who is engaged in begging must repeat this story of themselves, one where they are to be pitied.

Though most other Sama groups would abhor to be identified as beggars, I have observed that even other Sama groups can be found doing this in mainland Mindanao. I have observed Sama men and children not from the Sama Dilaut group begging at intersections and shopping malls in the Philippines. The self-projection of pitiful that Sama Dilaut have used for their financial benefit can negatively affect their own self-image as well as other Sama groups that interact with them.

These monkey battle stories, though told in the context of Sama groups that consider themselves quite different than the Sama Dilaut, are just as relevant to the Sama Dilaut as to the other Sama. Sama Dilaut fishermen in their rural communities have pushed themselves to great limits to provide fish and other ocean produce for their families, their communities, and the other groups in their society. A Sama Dilaut at his best is a very productive member of society. He is also very adept in an ocean environment. The Sama Dilaut are also brave. A leader who does not bend under pressure can be for a Sama Dilaut community very much like the bāt tagokan. His community stands firm and his relatives are not driven away because of the courage and bravery that he possesses. Since these stories are told in Sinama they are already in a form that the Sama Dilaut and many of the Sama of Zamboanga, Sulu, and TawiTawi can make use of for the moral education of their children.

\section{Conclusion}

My analysis of the Sama monkey tales is only the door opener for more research to be done on Sama storytelling. It is clear that Sama animal tales do not differ from the established functions of folklore. Careful investigation demonstrates how the stories combine the function of amusement with the functions of education concerning scientific and cultural knowledge as well as the function of social control. This method of examining the Sama monkey tales highlights Sama insights on the world around 
him and especially on the Sama relationship with the Tausug. The positive outcome in this analysis is that if these two stories can provide so much information on Sama culture, how they interact with their neighbours in Sulu, how and what they teach their children and what their values and morals are, then this stands as good reason to do further research and analysis of Sama oral traditions.

\section{References}

Arensen, J. E. (1991). Aspects of Language and Society Among the Murle of Sudan. Doctoral dissertation, Wolfson College, University of Cambridge, Cambridge, United Kingdom.

Bascom, W. R. (1965). Four Functions of Folklore. In A. Dundes (Ed.), The Study of Folklore (pp. 279-298). Englewood Cliffs, NJ: Prentice-Hall.

Behrens, D., \& Pack, J. (1973). Me' Kaba'-Kaba' duk Me' Kuya'. In D. Behrens \& J. Pack (Eds.), Kissa Yakan (A Collection of Yakan Folk Tales) (pp. 12-15). Manila: Summer Institute of Linguistics-Philippines.

Hunt, J. (1920). Some Particulars Relating to Sulo, in the Archipelago Felicia. Malayan Miscellanies, $1 . \quad$ Retrieved March 19, 2018, from http://www.sabrizain.org/malaya/library/miscellanies1.pdf

Janssen, M. (n.d.). Aarne-Thompson-Uther Classification of Folk Tales. Retrieved April 9, 2019, from http://www.mftd.org/index.php?action=atu\&act=range\&id=1299

McKinney, C. V. (2000). Globe Trotting in Sandals: A Field Guide to Cultural Research. Dallas, TX: SIL International.

Rizal, J. (1889). Two Eastern Fables. Trubner's Record, 3rd series, no. 247.

Stone, R. L. (1974). Intergroup Relations among the Tausug, Samal, and Badjaw of Sulu. In P. G. Gowing \& R. D. McAmis (Eds.), The Muslim Filipinos (pp. 74-99). Manila: Solidaridad Publishing House.

Thompson, S. (1946). The Folktale. New York: Dryden Press. 